Baltic Astronomy, vol. 6, 497, 1997.

\title{
A DETAILED INVESTIGATION OF ATMOSPHERIC EXTINCTION VIA VILNIUS PHOTOMETRY. ERRATA
}

\author{
M. C. Forbes ${ }^{1}$, R. J. Dodd ${ }^{2}$ and D. J. Sullivan ${ }^{1}$ \\ ${ }^{1}$ Victoria University of Wellington, P.O.Box 600, Wellington, New Zealand \\ ${ }^{2}$ Carter Observatory, P.O. Box 2909, Wellington, New Zealand
}

This paper, published in Baltic Astronomy Vol. 5 No. 2, pages 281-295, 1996, contains the following errors:

p. 281 in the title: should be PHOTOMETRY;

p. 282 in Eq. (2) should be $e^{-h / 7.996}$;

p. 283 in lines 5-6 from the bottom should be: of the altitude of a ground-based observatory;

p. 284 in line 8 from the bottom should be: $\alpha=\nu^{*}-2$;

p. 287 in Table 1: the units for the extinctions are mags/airmass and for the ozone absorption is $\mathrm{cm}^{-1}$.

After the author proofs were received, these errors were corrected in a part of copies of the journal. 
(C) Teorinès fizikos ir astronomijos institutas, 1997. ISSN 1392-0049.

Pasirašyta spausdinti 1997.VI.30. SL 637. Popieriaus formatas $70 \times 1001 / 16$. 8.25 sp.l. Tiražas 220 vnt. Spausdino Matematikos ir informatikos instituto jmone "Mokslo aidai", Vilnius, užsakymo Nr. 623. 